\title{
From pencil and eraser to blending materials and flipping the classroom: A short history of Teksredaksie and Text Editing
}

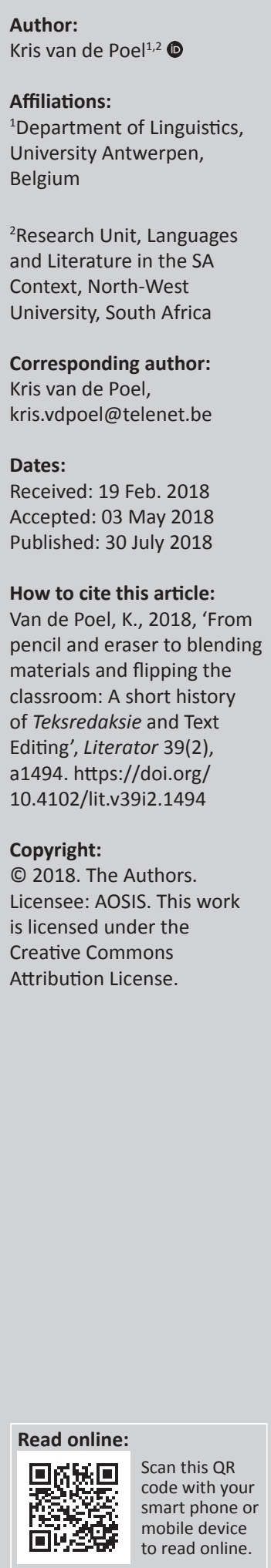

This article will take a historical perspective on the topic of text editing and highlight the following: (1) The origin and history of the Text Editing project and book productions in different languages (2003-2018) and (2) The latest programme developments from printed book to teaching with it, or learning from it and especially the development of a state-of-the-art training approach. In an attempt to evaluate whether these developments are defensible, also from the point of view of its users, a small-scale usability study was carried out among two groups of master's degree students $(N=37)$ who undertook inverted and/or flipped-blendedcollaborative text editing. As inverting classrooms with blended materials (online and contact) and introducing a collaborative approach to learning are innovative within this domain, the question of the programme's effectiveness deserves central attention. Quantitative and qualitative student evaluation data (online Likert-scale questionnaire with open questions and critical evaluation reports) show that Text Editing is more than a well-founded theoretical guide or handbook. The programme is experienced as authentic and effective and has a high impact on the users' self-efficacy and professional profile. As such the project is sustainable.

\section{Preamble}

\section{A (personal) history}

In a globalised high-paced world, it seems somewhat out of tune to talk about a project that has taken up a large part of a person's professional life for over 20 years. Nevertheless, this is the right time and place to give Wannie Carstens the credit for being the proponent of the academicisation of text editing, or 'teksredaksie' as the project was coined in Afrikaans. Under his impetus, text editing was brought out of the backroom into the linguistic limelight by highlighting its credibility and explicating its foundations, to be found in two of Carstens' other favourite areas of study, that is, normative and text linguistics, which were complemented by review studies on what, in linguistics at least, was the far less-developed domain of document design. Over time, these three 'strands' have given text editing a voice of its own.

Wannie Carstens has inspired, if not exactly a school, then at the very least a classroom of people, resulting in a wealth of outcomes that range from workshops to empirical studies, theses and PhDs, with repercussions for the professionalisation of the vocation from north (the low countries) to south (South Africa) and from east (Australia) to west (Canada). Thanks to his charisma, linguists and applied linguists alike now know that, in order to evaluate text quality, knowledge of normative linguistics is required to make well-founded judgements about linguistic right and wrong, whereas knowledge of text linguistics is the foundation for judgements about structure, texture and coherence of text (parts). Moreover, a text cannot survive without knowledge of document design, because texts are visual entities and it is, therefore, necessary to know how a text is put together and presented.

\section{Networking: Extending the team}

Even though the text editing products have been praised for their thoroughness and sound theoretical foundations, undoubtedly still the most valuable outcome of the project is that 'distant colleagues have become close friends who share the belief that the craft of text editing deserves the empirical underpinning of text linguistics to make it a full-blown scientific discipline' (Van de Poel 2003:1). In the past 15 years, this network has only increased and strengthened and, in true applied-linguistic fashion, text-linguistic insights have been married with normative and document design principles for better or for worse. This shows Carstens at his best as a pater 
familias or as Prof. Wannie (using a South African term of endearment), gathering his students around the table, the pool or the braai and enjoying the enthusiastic exchanges with a deeply rooted respect for everyone's contribution.

Since 2010, the pivotal Text Editing team has consisted of a theoretical linguist, who excels in reading and summarising research findings and who is renowned for his illegible handwriting and scribblings in pencil all over the page; an applied linguist, providing a pedagogical bridge between theory and practice; and a practitioner, providing sound grounding in the field. What binds the three together is that, through their experience and research, they are avid believers in the need for text editing to have solid foundations, at the same time acknowledging that theory is firmly rooted in practice and that, in turn, practice can benefit from teaching and training. An unassuming recognition that the domain can grow only by having the best craftspeople on board entitled the team to bring in colleagues who could shed light on several embedded topics. David Owen (Spain) expertly took on English as a Lingua Franca, and South-European English in particular; Catherine Grady (USA-Belgium) shared with us her lifelong experience of editing for multinational clients; Elizabeth Manning Murphy (Australia) added insights into editing regional variants with the focus on Strine; and Althea Kotzé (South Africa) contributed with her research findings on professionalisation requirements for text editors. But there were also the many volunteer editors who contributed with their editing tricks and tips, and the many (young) researchers who helped the team keep their focus.

Consequently, a lot of what has been written over the years has many fathers and mothers in the form of publications rooted in the lives, past and present, of the three authors, and the text editing story is heavily indebted to the Correspondence, Consistency and Correctness (CCC) model as conceived by Jan Renkema (the Netherlands) (1994, 1998a, $1998 b, 1999 a, 1999 b, 2002)$. As a result of a long period of intensive conceptualisation, the original framework has later been meticulously converted and extended to serve different languages (Afrikaans, English, Sesotho, German; others, e.g. Dutch, are currently works-in-progress), many purposes (training, learning, coaching, professionalisation, mentoring, etc.) and a wide audience from pre-professionals to professionals, and from proofreaders to ghost writers.

Being the applied linguist on the team, I will relate in this contribution how - over the years - the project has been datadriven at all times and how we have embedded text editing in teaching and training by trying to creatively extend the impact of what, at first, was destined to be just a printed book. This is the dynamic story of a dynamic topic.

\section{Doing and breathing text editing}

It has been said time and again: communicating effectively can mean all the difference between making money and losing it. Over time, text editing has become a fully integrated phase in the pursuit of effective written communication. However, whether performed by the author or editor of the text, in practice it is simply not enough to know the tricks of the text editing trade. Authors and text editors have to understand the knowledge underlying the skills and be able to apply it consistently, all the while being acutely aware of what they are doing. The concept at the core of the Text Editing project, therefore, is driven by the conviction that you turn out a better product when you know what you are doing, why you are doing it and to what end.

\section{Reflective needs analyses}

And so, from its early stages onwards, Text Editing exceeded the mere production of a book, because (we suppose) no one has ever become a text editor just by reading a handbook. As a project, Text Editing engaged in studying how to appropriately and adequately inform professionals as well as pre-professionals, raising their awareness and supporting their professional pride, training-the-trainer, gauging the potential of online mentorship, offering leverage to languages in need of standardisation and a rather lengthy list of etceteras. At all times during the programme development process, the needs of the stakeholders were therefore kept firmly in mind, because a defensible curriculum has to satisfy 'the language learning and teaching requirements of the students and teachers' (Brown 2009:269) within their professional context, be it a vocational training centre, institution of higher education, professionalisation course or autonomous learning trajectory.

Building a defensible language curriculum requires various types of analyses, among which constraints analysis plays an important role. In other words, it is important to create a 'balance between "what is needed" and "what is possible"' (Singh 1983:156), which can only be obtained by identifying the needs of the target group and the stakeholders (i.e. clients), at the same time acknowledging and analysing the (potential) constraints, while trying to translate those needs into a training programme (cf. Brown 2009; Nation \& Macalister 2010). In this way, it has the potential to become a responsible curriculum in that developers justify it with reference to theory and accept accountability for the development involved in this process (Weideman 2017).

The idea of working out some form of principled approach to the communication of texts arose in the late 1990s while co-teaching several courses on text linguistics with a focus on text quality. This 'flirtation' culminated in APIL 103, an Antwerp working paper (September 2003), with the running title Text Editing - a talent, an art or a scientific discipline, in which knowledgeable people in the field had been invited to cast their light on the topic.

The articles in APIL 103 (2003) addressed a wide range of topics: delineating the domain (Van de Poel), highlighting the needs for specific training (Teuwen), studying the way in which knowledge of text linguistics could play a role in training (Carstens), determining how language practitioners 
could be properly trained and professionalised (Kotzé \& Verhoef) and describing how stakeholders in the translation process could be empowered (Rodriguez). The issue concluded with the foundational paper by Johan Blaauw and Els Boets titled Towards a code of ethics for text editors. Since then, the code of ethics has brought about a process with which to draw practice into theory and theory into practice, and some of the concepts tentatively volunteered in the APIL have since been further developed in collaborative projects, master's degrees theses and PhDs. This proved to be a rich needs analysis, underlining the fact that the craft of text editing deserved empirical underpinning to make it a fullblown scientific discipline.

\section{Empirical data}

The wish to develop the project further into a reference guide, manual or handbook for (pre)professionals gave rise to some critical questions en route (as discussed in Verhoef, Carstens \& Van de Poel 2003) and it was decided that data input from the field was urgently needed to establish a name for the domain, enrich its theoretical foundations, understand how the editing process takes place and identify as well as delineate what is needed to ensure qualitative output and training. Part of the data was turned into an article developing the theoretical underpinnings of text editing and leading to a training blueprint that stipulated the following foundational and inservice training requirements (Van de Poel \& Carstens 2010):

- Text editors need to have an academic or professional degree, which could be a degree in language or literature, translation studies, journalism, communicology or similar (cf. Law \& Kruger 2008).

- Knowledge and skills have to be learned. Training then means actively engaging with distinct skills built on previously acquired knowledge.

- Training can take different forms. Basic training could either be language-oriented or content-oriented and should be supplemented with internships, specialised content courses and language courses, in-service training, on-the-job mentoring, refresher courses and so on.

- As 'up-to-date skills and abilities appropriate to the particular task' (Kemisho 2006) are required, new developments within the field have to be acquired through courses, conferences and workshops. In this way, new methods, sources, books and manuals do not have to form a threshold for professional functioning (cf. Du Plessis 1997:14-15; Kotzé 1998:137).

- Text editing should not be added as a single course within an existing programme (Glamann 2000). It has to be recognised as an independent educational track (cf. Law \& Kruger 2008:485) in order to adequately respond to the specific and professional needs of the text editing trade.

- Text editors have to establish their own weaknesses and strengths and keep close track of them in order to identify where extra training is required.

The 2010 article concluded that functioning as a professional in a professional context relies heavily on two factors: the level and extent of foundational training and the type of person interacting with it. As human beings, text editors' learning preferences and routines can vary greatly and training materials should, therefore, try to cater for this variety in order to optimise professionalism in the practice of text editing.

\section{Foundational linguistic work in different languages}

Supported by practitioners in different countries on the name-giving of this field, and having gained empirical insights into the procedural component of text editing as well as on basic training and ethical requirements, the development process of the materials was then completed. After the publication of Teksredaksie (2010), and after completely reworking and extending the materials for Text Editing (2012), in 2013 the project was redirected to include four major South African languages. This extension had been envisaged since the beginning of the project, and the core of the book in English was taken as the template for a set of books for African languages: isiZulu, isiXhosa, Setswana and others.

The research, writing, adaptation and translating process were supervised and guided by the original authoring team and by Justus Roux, scholar and African-language specialist, who took on the role of Series Editor. The collaborations took off in earnest with a workshop held at the University of Johannesburg in January 2014, and Text Editing for African Languages became a formally registered academic research project hosted by the Research Unit for Language and Literatures in the South African Context at North-West University, Potchefstroom. It was sponsored by the South African Book Development Council, the National Arts Council for South Africa, Fibre Processing \& Manufacturing Sector Education and Training Authority (FP\&M SETA) and the South African Translators' Institute (SATI), among others.

By the end of 2014, the isiXhosa and Sesotho authors were so well advanced with their work that they were joined by two colleagues, seasoned SATI members, one to partner with each author in the role of evaluator and peer reviewer. The author-researchers worked per language on the adaptation of Text Editing to its equivalents aimed at practitioners in these languages and covered the following topics:

- the domain of text editing

- the status and standardisation of African languages

- adopting and developing materials

- the essence of project management

- writing a book: some requirements for authors

- the future of Text Editing.

In essence, the project contributed to the standardisation of four major indigenous South African languages and thus also to effective multilingualism in South Africa. The project was seen as an opportunity to train text editors in peer review, proofreading and indexing and was painstakingly managed by McGillivray Linnegar Associates. 
In 2016, Text Editing was published in Sesotho with the title Metheo ya ditokiso tsa sengolwa, authored by Dr Nyefolo Elias Malete from the School of Languages at the University of Free State and presented to an attentive and enthusiastic audience. The book was called a 'pioneering guide for language practitioners' by Mbulungeni Madiba (past Chairperson of Pan South African Language Board [PanSALB]) and 'a "must-have" for writers, editors and proofreaders, and even teachers, whose first language is Sesotho'. The other languages are still work-in-progress with new members added to the teams to keep the work going.

\section{Foundational pedagogical work: Teaching, learning, training, coaching and mentoring}

With three books out and more in progress in other languages, it was time to reflect on extending the delivery of content to an ever-changing professional field in a lifelong learning context. In the second part of this article, I will report on how the pedagogical approach surrounding text editing evolved from providing readers with a contact mail address (2012) to presenting a blend of materials and online mentoring trainees (2017) and present one way in which text editing training is now being provided for pre-professionals.

\section{A book is a book ... is a book, and is not a book}

Over time, the Text Editing books have been well received. This may be because the authors come from varying professional domains (public and private enterprise), take different approaches (theoretical and applied, hands-on and reflective), have different language backgrounds (even different types of English), are rooted in different continents (Europe and Africa, with inclusion of perspectives from the USA and Australia) and approach text editing in slightly different ways (inward- and outward-looking, theoretical, practical and applied). Each author in their own right has contributed and has been inspired and fed by many others in the field as pointed out above.

The book gives full recognition to the role of the text editor in a wide range of guises, including that of freelancer, project manager, proofreader and 'ghost writer', as well as that of practitioner in corporate or educational environments, dealing with print and/or digital media. It details the critical, normative and text-linguistic challenges that are likely to confront English-language practitioners as they work through authors' writings. If there is a central message that forms a leitmotiv, it is that, like weaving, text editing is a process and one that should be undertaken systematically.

Over the course of the years, we have stayed true to this principle, but the original framework has been meticulously extended to serve a broader purpose and a wider audience. Indeed, there are different ways to go about the final stage of the creative writing process: either authors revise their own text in a re-reading phase, helped by a series of online tools and in which they themselves determine what 'adapting' means (Bisaillon 2007:76), or else they ask another person to read their text critically and to correct, adapt or improve it (Bisaillon 2007:76; Mossop 2001, 2007). In this latter case, they enter into a peer-to-peer or a professional-to-client relationship. During this quality assessment process, some of those critical readers will consider the communicative effect of the text as the most important aspect, and adaptation to diverse readerships will become a priority, whereas others will focus on 'dots and commas' in order to improve the text; yet, others will focus on the form and the lexical appropriateness of the text. Whatever the focus, the goal is to make the transmission of the message as effective as possible.

Text Editing tries to balance both strands. It is, therefore, not only an important and useful point of entry into the profession of text editing for neophytes but also an essential back-tobasics guide for practising editors. As human beings scan, skim, read and internalise knowledge in different ways, the content has been presented in diverse ways, too. The many lists, checklists, tabulated matter and diagrams have proven to be supportive and useful as easy reference.

However, as trainers of text editors making full use of the book, we have felt over time that a textual paper-based review of theories and practice does not do the art and craft of the profession full justice. There is more to text editing than reading up on what others have to say about the topic. So, to address this, the programme has gone blended in order to ensure full and rich coverage of all features involved. Text Editing-The Programme now consists of a printed book, which still can be read as a stand-alone guide or reference manual to the topic, but which has been complemented with online materials: reflection tasks, editing assignments, a library with additional in-depth reading materials, critical input from specialists in the field and an online community of practitioners to ensure full support en route. As the programme in this form is relatively new and has only been run twice at the University of Antwerp, it is necessary to adopt a critical approach and evaluate it in line with the desire to be defensible and responsible.

\section{A syllabus for blending and flipping}

\section{The programme's objectives and outcomes}

Starting from the questions 'what level of intervention is required to make written texts communicate as effectively as possible and which learning and training tools can be presented to meet this goal?', the team of developers has addressed a set of fundamental issues in the course of the syllabus-development process given as follows:

- What foundational knowledge is required to inform the text editing skills of trainees?

- How can the process of editing texts be effectively trained?

- How can knowledge and skills be presented in a balanced and integrated way? 
- What tools and deliverables are needed to support the training process online and offline?

- What channel is best suited to distinct types of learners, assignments and outcomes?

It was decided to rely on what seemed to work best in our workshops and lectures and therefore to have participants work through the different phases of text editing on the basis of several authentic texts, while being guided and supported by theoretical reflections in the book, pointers from international specialists in the field and individual feedback from a writing consultant. In this way, content and delivery became blended, while keeping the original objectives in mind where learners gain insights into the following:

- the level of intervention required to make texts communicate effectively

- what the process of writing and editing texts involves

- what constitutes a text editor's complex craft.

\section{Programme components}

To this end, trainees have access to different tools and, despite earlier claims to the opposite (Glamann 2000; Law \& Kruger 2008), the Antwerp text editing programme (www. interculturate.org) is currently run as a Master's degree course for students with a language degree. More particularly, it starts with a short profile test, assessing the participant's editing profile and providing them with insights in their strengths and weaknesses. Further, it consists of 10 topics spread across 10 weeks with a similar procedure to be completed for every topic and for every week (see screenshot of some components of Chapter 2 in Appendix 1). The combination of theoretical reflection and practical work reinforces each other:

- Reflection through hands-on experience. This is autonomous text editing work in the form of a reiterative process based on progressive insight and on feedback from a tutor or author, which then has to be translated into a more adequate text. The editing work culminates in a portfolio containing seven reworked texts.

- Textbook reading (one foundational and one applied module) on how to make texts communicate effectively (Van de Poel, Linnegar \& Carstens 2017).

- Assignments are short training exercises focussing on particular text editing issues.

- Meeting the expert in video testimonials where key points on the textbook reading are being highlighted.

- Discussing a key point from the experts' presentation in the online and closed community of practice, which leads to a take-home message as part of the participants' final portfolio.

\section{A blended and inverted approach}

The programme takes a blended-learning approach, combining 'face-to-face instruction with computer-mediated instruction' (Graham 2006:5). Provided that the online component is not just a mirror copy of in-class content, or a 'data dump' of this, the approach can turn learners into co-owners of the teaching and learning process in a true constructivist spirit (Van de Poel \& Fourie 2013). In this course's particular blend, face-to-face (also called F2F) interaction is mixed with independent study via technology. Students do an editing assignment and prepare readings at home, then come to class armed with some background knowledge and questions. The contact sessions were limited to $5 \mathrm{~h}$ (instead of the traditional $40 \mathrm{~h}$ ) as most of the work was carried out online and in the virtual community. During contact sessions, the various topics were either briefly introduced or discussed in detail. In this way, the weekly sessions with theoretical introductions, tutorials, discussion sessions and group discussions on assignments primarily took place online, in the students own space and time. This means that the overall approach is not only one of blending technologies but also inverting the classroom (Lage \& Platt 2000) (https://www.teachthought.com/learning/thedefinition-of-the-flipped-classroom/). In higher education, the need for programmes to be effective has gained attention by focussing on learner engagement. Effectively using inclass time in a student-centred way refers to the 'flipped' or inverted classroom where the time spent in face-to-face contact is primarily devoted to knowledge application (Pluta, Richards \& Mutnick 2013), but 'it may also allow the teacher a better opportunity to detect errors in thinking' (O'Flaherty \& Phillips 2015). In the case of text editing, the contact sessions were used for problem-solving and interacting with author queries, rather than applying knowledge or doing exercises in order to facilitate the participants' engagement with the models and materials.

Blended learning or flipped classrooms are not necessarily collaborative in nature (for a comprehensive discussion of the relationship between collaboration and the new media, see Ludwig \& Van de Poel 2017), but, in a profession such as text editing, collaboration and team work are a prerequisite and this requires social skills. Especially for foreign-language students, interaction can be regarded as an opportunity to collaborate in solving language-related problems, in scaffolding one another, and in co-constructing new language knowledge (cf. Donato 1994; Luzzatto \& Di Marco 2010; Ohta \& Foster 2005; Swain 2000).

This approach requires a high degree of learner autonomy, which is exactly what professionalisation is about. Senior students can be expected to have gained some considerable degree of learner autonomy, but venturing into a new vocational area can prove challenging and daunting. It appeals to the learner as a person and manager. As stated in the literature, learners can and should be encouraged to take control of planning, monitoring and evaluating the learning process and outcome and show willingness and motivation to initiate and regulate their learning (Little 2004; Murray 2014; Nguyen \& Gu 2013). Learners, therefore, have to be supported in a true autonomy-spirit. Supporting and guiding them through the distinct text editing topics in a limited contact environment requires a carefully considered and 
planned schedule in which the programme components are clearly defined. It is particularly important to provide support systems that facilitate participants' taking ownership of their learning (cf. Stracke 2007).

\section{Evaluation and the way forward}

The question that remains to be answered in this final section is whether a blended and flipped collaborative approach works for text editing and whether it provides the added value that is hoped for. I will, therefore, briefly report on the usability study, containing quantitative and qualitative data, carried out among the 2017 Master's degree students who undertook flipped-blended-collaborative text editing.

The students who took part in the two 2017 courses $(N=37$ in total) completed an online usability study at the end of the course to help us evaluate course components in line with the demands to generate a responsible design (see Appendix 2 for instructions and some examples; the questionnaire consists of 70 questions; it can be obtained from author upon request). This study aims to generate a 'systematic approach to program design' by reflecting on its different components, including goals, objectives, selection and sequencing of materials, pedagogical approach, and evaluation (Gasiorek \& Van de Poel 2017:57). The questionnaire data are further enriched by qualitative data derived from the open-comment boxes in the usability study, reflective procedural evaluations of students' training experience (weekly blogs) and final reflective essays on the editing experience.

\section{The blended and flipped approach}

Students were very positive about the blended approach, with an overwhelming majority (85\%) saying that it was helpful in achieving the programme's objectives, almost three-quarters (70\%) agreeing that it was a workable substitute for traditional contact teaching. With programme activities being labelled as varied (75\%) and editing assignments as interesting $(84 \%)$ and intellectually exciting $(84 \%)$, the participants valued the feedback given by the tutor on their editing assignments as useful (70\%). Feedback on editing tasks was regarded to be sufficient because the tutor's feedback was supplemented with author queries. Two-thirds of the respondents $(67 \%)$ regarded the content as well suited to the online medium, whereas almost all (92\%) found it to be well suited to flipped learning. A majority (67\%) also felt that the flipped approach had made them more autonomous.

Students valued the autonomy; in this respect, relevant comments included the following:

'I liked being able to do the course on my own pace via blended learning.' (S1-G1)

'I liked being able to balance my own activities.' (S2-G2)

'Choosing your own work pace was pleasant.' (S3-G2)

\section{Course components}

The reading materials were experienced as helpful for completing the activities (78\%) and informative (83\%).
Two-thirds (75\%) felt that the book made a positive contribution to the programme as a whole.

Students commented as follows:

'Structuring the course via a handbook was useful.' (S11-G1)

'The textbook was extremely useful and interesting, I learned a lot from this book.' (S12-G2)

'Explanations that were given in the textbook about errors could be immediately implemented in the assignments when using comments and track changes.' (S5-G1)

The trainees felt that the various programme components supported each other:

'Work field experience was interesting and clearly linked to the chapters.' (S7-G2)

The short video interventions by the experts met with a slightly mixed enthusiasm, with just under two-thirds of the students $(60 \%)$ finding the input of experts helpful for focussing on specific aspects of writing and editing, but $83 \%$ experiencing the instructions for self-reflection as helpful for focussing on key issues.

Comments given included the following:

'The support given in the videos was really necessary and a good supplement to the contact classes.' (S8-G1)

'I think that slightly extended audio or video files [would] be even better.' (S12-G2)

'The contact classes gave us the opportunity to really talk about what has to be done in text editing.' (S6-G1)

'It is really possible to become a text editor with the support in the videos and some contact classes!' (S13-G2)

\section{Online and offline contact}

The discussion forum or community of practice, as a form of low-threshold virtual contact, was not very positively embraced when the group as a whole had to engage in it; but when the discussion sessions were changed into groups of four, a majority of the group evaluated this component positively as an integrated part of the programme. As this is a relatively new form of collaborative learning, the following comment is positive because the editing assignments led to collaborative learning:

'I think we have all relied on our peers for the editing tasks.' (S7-G2)

Contact sessions (which were very limited) were positively evaluated all the way through as helpful (92\%), sufficient $(66 \%)$, informative $(100 \%)$, useful $(92 \%)$ and perceived as adding value to the course overall (100\%). At the same time, over two-thirds $(67 \%)$ of students evaluated the minimal classroom contact as appropriate.

\section{The project's impact and sustainability}

Finally, evaluation of the programme's impact was overwhelmingly positive, with a majority $(84 \%)$ claiming 
that the course had helped them to become a text editor (even of their own writing), that it had improved their writing (84\%) and that it had met their expectations (78\%). Last but not least, all students (100\%) were convinced that it had helped them to learn to evaluate written texts critically. One participant formulated it in the following way:

'I have learned how versatile text editing is and how to become a better editor of my own texts.' (S4-G1)

If nothing else, this small-scale evaluation shows that Text Editing is much more than a theoretically well-founded handbook; rather, it is one that still has further developmental potential, even 15 years down the line. Follow-up studies will take the topic further into different directions.

\section{Epilogue}

Text Editing has been a project for a long time. In the end, it is up to the users, pre-professionals and professionals alike, to evaluate its content, approach, relevance, sufficiency, efficiency, impact and so on, and make it a sustainable product. When participants exclaim in delight that they had never realised that becoming a text editor was really a professional opportunity and not just the talent of dedicated amanuenses or scribes in a stuffy back office, the goal would truly seem to have been realised. It is heart-warming to see them take a step back and think in earnest about the ins and outs of a significant trade or to put it in their own words:

'Text editing is a lot more than just fishing out the grammar and spelling mistakes.' (S1-G1)

Or as another budding text editor puts it:

'At first, I thought an editor's job is no more than proofreading, which simply means to detect the typos, punctuation errors or grammatical mistakes, etc. After this ten-week program, I come to realise that in order to make a text flow better, editing means far more than simply making corrections. To start with, an editor should have an encyclopaedic knowledge. An editor's job is to facilitate communication, therefore background knowledge on a particular subject is required to enable an editor to help writers get their idea across ... Moreover, editors should be able to cope when the original author is not available ... At last, editing should always be reader-centred with regard to spelling, layout and typography.' (S2-G2)

Finally, it is pointed out that:

'... the guidelines in the textbook and the videos make everything more manageable. I am now aware of issues that have never occurred to me before, e.g. congruence of facts ... and appropriate wording.' (S2-G3)

The Text Editing journey has been an exciting one, starting in the post-apartheid era with the establishment of a bilateral agreement and exchange programme for young researchers, which gradually turned into a multinational and multilingual project on a topic that became a likeable, defensible, justifiable, responsible and adult study domain.

\section{Post script}

It was an honour for me to walk this journey with Wannie Carstens. We have ventured out into the unknown, but have always found our feet. I have enjoyed every moment, and even though Wannie - for his part - now takes a step back, this will not at all be the end of a worthwhile project.

\section{Acknowledgements Competing interests}

The author declares that she has no financial or personal relationships which may have inappropriately influenced her in writing this article.

\section{References}

Bisaillon, J., 2007, 'Professional editing: Emphasis on the quality of a text and its communicative effectiveness', in D. Alamargot, P. Terrier \& J.-M. Cellier (eds.) Written documents in the workplace, pp. 75-94, Elsevier, Amsterdam.

Brown, J.D., 2009, 'Foreign and second language needs analysis', in M.H. Long \& C.J. Doughty (eds.), The handbook of language teaching, pp. 269-293, WileyBlackwell, West Sussex

Carstens, W.A.M. \& Van de Poel, K., 2011, Teksredaksie, 2nd edn., African Sun Media, Stellenbosch.

Donato, R., 1994, 'Collective scaffolding in second language learning', in J.P. Lantolf \& G. Appel (eds.), Vygotskian approaches to second language research, pp. 33-55, Ablex Pbls., Westport.

Du Plessis, A., 1997, 'Die teorie en praktyk van taalversorging - 'n Loodsondersoek', MA thesis, Potchefstroomse Universiteit vir Christelike Hoër Onderwys.

Gasiorek, J. \& Van de Poel, K., 2017, 'Language-specific skills in intercultural healthcare communication: Comparing perceived preparedness and skills in nurses' first and second languages', Nurse Education Today 61, 54-59. https://doi.org/10.1016/j. nedt.2017.11.008

Glamann, H., 2000, How papers can find and retain copy editors, viewed 17 November 2006, from http://www.copydesk.org/words/ASNEFebruary.htm

Graham, R.G., 2006, 'Blended learning systems - Definition, current trends, and future directions', in C.J. Bonk \& R.G. Graham (eds.), The handbook of blended learning: Global perspectives, local designs, pp. 3-21, Pfeiffer, San Francisco, CA.

Kemisho, S., 2006, Professionalism, Muratho, s.I., p. 39.

Kotze, A., 1998, 'Die teksversorger as spookskrywer: Christelike uitgewersmaatskappye as 'n gevallestudie', MA thesis, Potchefstroomse Universiteit vir Christelike Hoër Onderwys.

Lage, M. \& Platt, G., 2000, 'The internet and the inverted classroom', Journal of Economic Education 31, 11. https://doi.org/10.1080/00220480009596756

Law, M.A. \& Kruger, H., 2008, 'Towards the professionalisation of editing in South Africa', Southern African Linguistics and Applied Language Studies 26(4), 479-493. https://doi.org/10.2989/SALALS.2008.26.4.6.678

Little, D., 2004, 'Democracy, discourse and learner autonomy in the foreign language classroom', Utbildning \& Demokrati 13(3), 105-126.

Ludwig, C. \& Van de Poel, K. (eds.), 2017, Collaborative learning and new media Insights into an evolving field, Peter Lang, Frankfurt am Main.

Luzzatto, E. \& Di Marco, G. (eds.), 2010, Collaborative learning, methodology, types of interactions and techniques. Nova Science Publishers, New York.

Malete, N.E., 2016, Metheo ya ditokiso tsa sengolwa, MLA Publications, Milnerton.

Mossop, B., 2001, Revising and editing for translators, St. Jerome Publishing, Manchester.

Mossop, B., 2007, Revising and editing for translators, 2nd revised edn., St. Jerome Publishing, Manchester.

Murray, G., 2014, Social dimensions of autonomy, Palgrave Macmillan, Basingstoke.

Nation, I.S.P. \& Macalister, J., 2010, Language curriculum design, Routledge, New York.

Nguyen, L.T.C. \& Gu, Y., 2013, 'Strategy-based instruction: A learner-focused approach to developing learner autonomy', Language Teaching Research 17(1), 9-30. https://doi.org/10.1177/1362168812457528

O'Flaherty, J. \& Phillips, C., 2015, 'The use of flipped classrooms in higher education: A scoping review', Internet and Higher Education 25, 85-95. https://doi.org/ 10.1016/j.iheduc.2015.02.002

Ohta, A.S. \& Foster, P., 2005, 'Negotiation for meaning and peer assistance in second language classrooms', Applied Linguistics 26(3), 402-430. https://doi.org/ 10.1093/applin/ami014

Pluta, W., Richards, B. \& Mutnick, A., 2013, 'PBL and beyond: Trends in collaborative learning', Teaching and Learning in Medicine 25(Suppl 1), S9-S16. https://doi.org /10.1080/10401334.2013.842917

Renkema, J., 1994, 'Het beoordelen van tekstkwaliteit', Onze Taal 63, 82-84. 
Renkema, J., 1998a, 'Correspondentie, consistentie en correctheid in schriftelijke communicatie', in V. Damoiseaux \& A.A. van Ruler (eds.), Effectiviteit in het communicatiemanagement: Een zoektocht naar criteria voor succes, pp. 39-54, Samsom, Deventer.

Renkema, J., 1998b, 'De C3-analyse', Tekst[blad] 4, 29-31.

Renkema, J., 1999a, 'Een raamwerk voor tekstdiagnose: Het CCC-model (Deel 1)', Ad Rem: Tijdschrift voor Zakelijke Communicatie 13(4), 1-5.

Renkema, J., 1999b, 'Een raamwerk voor tekstdiagnose: Het CCC-model (Deel 2)', Ad Rem: Tijdschrift voor Zakelijke Communicatie 13(5), 1-5.

Renkema, J., 2002, 'Over smaak valt goed te twisten: Een evaluatiemodel voor tekstkwaliteit', in F. van Eemeren, P. van den Hoven, C. Jansen \& P.J. Schellens (eds.), Tussenstand. 25 jaar tijdschrift voor taalbeheersing, pp. 177-190, Van Gorcum, Assen.

Singh, R.K. 1983. 'ESP: Communication constraints', System 11(2), 155-158. https:// doi.org/10.1016/0346-251X(83)90026-X

Stracke, C.M., 2007, Quality standards for quality development in e-learning: Adoption, implementation, and adaptation of ISO/IEC 19796-1, viewed March 2016, from http://www.qed-info.de/downloads

Swain, M., 2000, 'The output hypothesis and beyond: Mediating acquisition through collaborative dialogue', in J.P. Lantolf (ed.), Sociocultural theory and second collaborative dialogue', in J.P. Lantolf (ed.), Sociocultural theor
language learning, pp. 97-114, Oxford University Press, Oxford.
TeachThought, n.d., Flipped feedback, viewed January 2018, from https://www. teachthought.com/learning/the-definition-of-the-flipped-classroom/

Van de Poel, K. (ed.), 2003, 'Text editing - From a talent to a scientific discipline', in Antwerp papers in linguistics, p. 103, Universiteit Antwerpen, Antwerpen.

Van de Poel, K. \& Carstens, W.A.M., 2010, 'Tekstredactie - Een wetenschappelijke onderbouw voor de praktijk', Tydskrif vir Nederlands en Afrikaans 17(1), 53-79.

Van de Poel, K., Carstens, W.A.M. \& Linnegar, J., 2012, Text editing. A handbook for students and practitioners, UPA Editions, Brussels.

Van de Poel, K. \& Fourie, C., 2013, 'A critical approach to the development of blended medical communication training materials', Stellenbosch Papers in Linguistics Plus 42, 333-351. https://doi.org/10.5842/42-0-149

Van de Poel, K., Linnegar, J. \& Carstens, W.A.M., 2017, EdiText. Making texts communicate effectively, InterCulturate, Antwerpen.

Verhoef, M., Carstens, W.A.M. \& Van de Poel, K., 2003, 'Op weg na 'n koherente siening van die taal- en tekspraktyk', Literator 24(3), 15-29. https://doi. org/10.4102/lit.v24i3.299

Weideman, A., 2017, Responsible design in applied linguistics: Theory and practice, Springer, Switzerland. 


\section{Appendix 1}

4 Chapter 1 - Text Quality

Chapter 3 - Text linguistics

\section{Chapter 2 - Normative linguistics}

Your progress (?

Reflection: Arab media I

Instruction: Improve the text using Track Changes and Comments.

Name your text version Arabmedia1_Firstname_LASTNAME

Reflection: Choose one of three

Instruction:

Select one of the following texts.

By week 10 improve the text by using Track Changes (no Comments). Also provide a clean final version (accept all changes - no Markup):

1. Informative/instructive text: How do I claim maintenance?

2. Narrative text: Introduction to literary genre

3. Descriptive text: How Welsh hospitality and culture influenced Belgian interior design in the Modernist era: the case of Elisabeth De Saedeleer

Reading: ediText
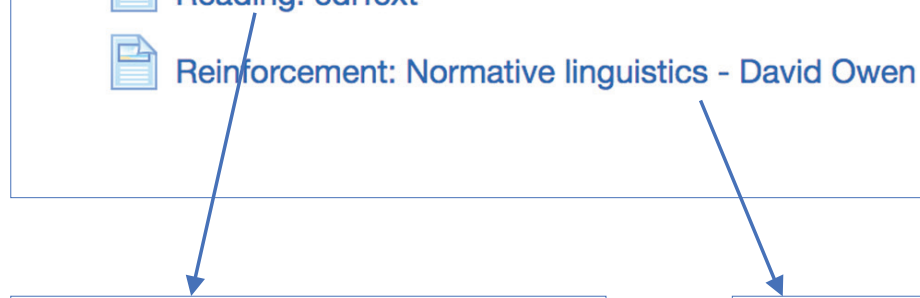

Reading: ediText

The reading for the current unit can be found in the ediText book Chapter 2 - Normative linguistics and text quality

Overview and Introduction

1. Normative linguistics and text quality

1.1 Normative linguistics as a field of study

1.1.1 The foundations for 'norm'

1.1.2 Norms versus conventions

1.2 Standard language as norm

1.3 The boundaries of normative studies

2. Knowledge of sources

2.1 Rationale for indepth knowledge of sources

2.2 Criteria for the appropriateness of sources

3. Types of language norm

3.1 Judgements of grammaticality

3.1.1 Internal norms of English syntax

3.1.2 Internal norms of English morphology

3.2 Pragmatic correctness

3.2.1 Internal norms of semantics

3.2.2 External norms of semantics

3.3 Appropriate language use

3.1 Externa noms of English spelling and puncusion $p 28$

3.3.2 External norms of standard language

3.2.4 External norms of style

Summary and conclusion
Reinforcement: Normative linguistics - David Owen

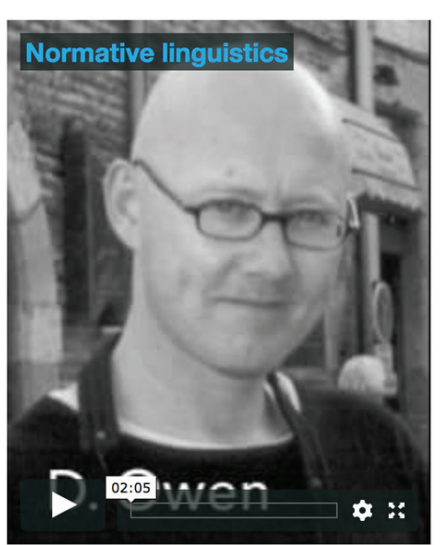

\section{Watch the video.}

Before the weekend post your reflection (a question, a comment, ...) on the topic in your community chat (group 1 or group 2).

This is the input for your online discussions during the week. You can start a new thread for a new topic. Before the next week starts (Thursday 13:00) formulate a take-home message based on the group discussion.

FIGURE 1-A1: Online text editing: Chapter 2 an overview. 


\section{Appendix 2}

\section{Instructions for the online post-course evaluation questionnaire}

Thank you for taking the text editing course.

We hope that you enjoyed using the materials and that it was a good learning experience.

Please complete this short survey to give us some feedback on your experience. The results will be used to improve the materials and approach. Your name will be used for internal purposes only. There are no right or wrong answers; we are interested in your opinion only. Please add any comments you want. We are grateful that you are taking the time to complete this questionnaire.

Thank you!

John Linnegar

Kris Van de Poel

Please respond to the following statements. Feel free to add comments, examples or additional information.

$\cdots$

You are making it possible to improve this pioneering course for future generations through your participation in this survey. Thank you.

Example:

Please respond to the following statements. Feel free to add comments, examples, or additional information.

1. The course was well structured.

Strongly agree $\bigcirc$ Agree $\bigcirc$ Neither agree nor disagree $\bigcirc$ Disagree $\bigcirc$ Strongly disagree

My comment

\section{The blended approach to learning was helpful in attaining the course's objectives. \\ $\bigcirc$ Strongly agree $\bigcirc$ Agree $\bigcirc$ Neither agree nor disagree $\bigcirc$ Disagree $\bigcirc$ Strongly disagree}

My comment

3. The blended approach was a workable substitute for 'traditional' contact teaching. Strongly agree Agree Neither agree nor disagree

Disagree Strongly disagree

My comment 